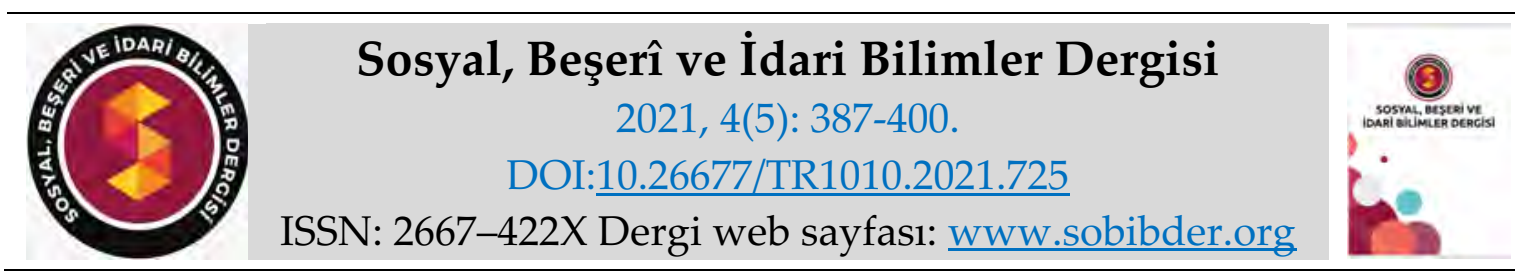

ARASTTIRMA MAKALESI

\title{
El Sanatlarının Turizme Katkısı, Mevcut Durumu Sorunları ve Çözüm Önerileri Üzerinde Sinop Örneğinde Bir Araştırma
}

Aslı Sultan EREN, Yüksek Lisans Öğrencisi, Hacı Bektaş Veli Üniversitesi, Turizm Araştırmaları Enstitüsü, Nevşehir, e-posta: aslisultan12@gmail.com

ORCID: https://orcid.org/0000-0002-1173-2560

Doç. Dr. Gül ERKOL BAYRAM, Sinop Üniversitesi, Turizm İşletmeciliği ve Otelcilik Yüksekokulu, Sinop, e-posta: gulerkol@sinop.edu.tr

ORCID: https://orcid.org/0000-0001-9764-2883

Öz

Çalışma, Sinop için önemli bir turistik ürün olan el sanatlarının karşılaştığı problemleri tespit etmek, el sanatlarının sürdürülebilirliğin sağlaması ve turizme olan katkısının artırılması hususunda Sinop ili ve bölge turizmi açısından büyük önem taşımaktadır. Çalışmanın amacı; Sinop'un geleneksel el sanatları üretiminde yaşanılan sorunlarına çözüm bulmak ve Sinop'un el sanatlarının turizme olan katkısını artırmaktır. Çalışmada nitel araştırma yöntemlerinden mülakat tekniği tercih edilmiştir. Zanaatkârlarla yapılan görüşmelerin sonunda araştırma doğrultusunda elde edilen sonuçlar; kalifiye eleman yetiştirmede yaşanan zorluk, hammaddeye ulaşım sıkıntısı, el sanatları hakkında halkın bilgilendirilmesi, zanaatkârlar için teşvik faaliyetleri ve Sinop ilinin tanıtım faaliyetleri konuları hakkında belediye çalışmaları yapılması gerektiği tespit edilmiştir.

Anahtar Kelimeler: El Sanatları, Turizm, Kültür Turizmi, Sinop.

Makale Gönderme Tarihi: 23.12.2020

Makale Kabul Tarihi: 01.05.2021

\section{Önerilen Atıf:}

Eren, A. S. ve Erkol Bayram, G. (2021). El Sanatlarının Turizme Katkısı, Mevcut Durumu Sorunları ve Çözüm Önerileri Üzerinde Sinop Örneğinde Bir Araştırma, Sosyal, Beşeri ve İdari Bilimler Dergisi, 4(5): 387-400.

(C) 2021 Sosyal, Beşerî ve İdari Bilimler Dergisi. 


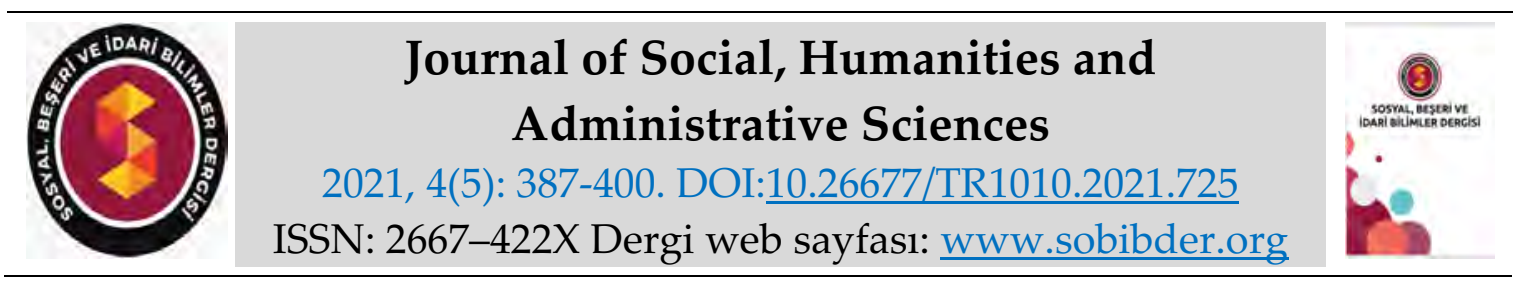

\title{
RESEARCH PAPER
}

\section{Contribution of Handicraft to Tourism, Current Situation on Problems and Solution Recommendations: A Sinop Example}

Aslı Sultan EREN, MSc. Student, Hacı Bektaş Veli University, Tourism Research Institute, Nevşehir, e-mail: aslisultan12@gmail.com

ORCID: https://orcid.org/0000-0002-1173-2560

Associate Prof. Dr. Gül ERKOL BAYRAM, Sinop University, School of Tourism and Hotel Management, Sinop, e-mail: gulerkol@sinop.edu.tr

ORCID: https://orcid.org/0000-0001-9764-2883

\begin{abstract}
The study is of great importance for Sinop province and regional tourism in determining the problems faced by handicrafts, which is an important touristic product for Sinop, ensuring sustainability of handicrafts and increasing their contribution to tourism. The aim of the study; to find solutions to the problems of Sinop's traditional handicraft production and to increase the contribution of Sinop's handicrafts to tourism. Interview technique was preferred among qualitative research methods in the study. The results obtained in line with the research at the end of the interviews with the craftsmen; It has been determined that municipal studies should be carried out on the difficulties in raising qualified personnel, the problem of access to raw materials, informing the public about handicrafts, incentive activities for artisans and promotional activities of the province of Sinop.
\end{abstract}

Keywords: Handcraft, Tourism, Culture Tourism, Sinop.

Received: 23.12 .2020

Accepted: 01.05.2021

\section{Suggested Citation:}

Eren, A. S. and Erkol Bayram, G. (2021). Contribution of Handicraft to Tourism, Current Situation on Problems and Solution Recommendations: A Sinop Example, Journal of Social, Humanities and Administrative Sciences, 4(5): 387-400.

(c) 2021 Sosyal, Beşerî ve İdari Bilimler Dergisi. 


\section{Gíriş}

Bilindiği üzere turizm, kültür alışverişinin en kolay yoludur. Turizm aracılığı ile pek çok farklı kültürle tanışıp kültür alışverişi yapabilmek mümkündür. Turizm, kişilere yalnız farklı kültürleri tanıma fırsatı sunmaz, bunun yanında yöre halkına, sahip oldukları maddi ve manevi değerleri de pazarlama fırsatı sunmaktadır. Alternatif turizm çeşitleri sayesinde en kırsal alanların bile turizme katılması sağlanmış, doğal, tarihi ve kültürel çekiciliği olan her bölge turizme açık hale gelmiştir.

Son yıllarda şehir hayatında stresli bir yaşam süren insanların kendini keşfetme isteği doğrultusunda kırsal alanlara gitmesiyle ortaya çıkan kırsal turizm, yöre halkına yeni bir istihdam fırsatı doğurmuştur (Kesici, 2012: 33-37). Şehirde yaşayan insanlar kırsal alanlara çoğunlukla; akraba ziyareti, günübirlik geziler için gitmektedir. Bu ziyaretlerin asıl amacı, baskıcı ve stresli şehir hayatından bir süre uzaklaşma ve özgür hissetmektir. Bu ziyaretlerin çoğalması, kırsal alanlara yoğun bir turist akışı sayesinde de "kırsal turizm" kavramı ortaya çıkmıştır (Aydın ve Selvi, 2012: 39-46).

Kırsal turizm, yalnızca turist-yerel halk arasında kültür alışverişi sağlamamakta, yörenin altyapısını geliştirmesine ve yerel halkın ek gelir sağlamasına da katkıda bulunmaktadır (Torun, 2013: 32). Bu katkılar arasında yerel halkın el emeği göz nuru el sanatları da yer almaktadır. Yerel halkın verdiği uzun uğraş ve emeklerin sonunda ortaya çıkan ürünlerin yöre adetlerine göre sergilenmesi ve pazara açılması kırsal turizm faaliyetleri içinde yapılmakta ve büyük önem arz etmektedir (Etikan ve Çukur, 2011:4). Geleneksel el sanatları adı altında ortaya çıkan ürünler; bulundukları toplumun sosyo-kültürel yapısını, ortaya çıktıkları döneme ait özellikleri ve tarihi önem arz eden olayları konu aldığı için büyük önem taşımakla birlikte bir kültür aktarım aracıdır (Altıntaş 2016: 162; Akın, 2018:242). Bunun yanı sıra geleneksel el sanatları, maddi yarar sağlaması, iş imkânı sunması, yöresel kaynakların kullanımı açısından oldukça önemlidir. (Özcüre ve Yavuz 2006: 168; Akın, 2018:242). Çalışma Sinop iline ait yöresel el sanatlarının üretim aşamasından pazarlama aşamasına kadar geçtiği süreçte yaşadığı sorunlara çözüm bulmak ve turizm sektöründe yöresel el sanatlarının kullanımını artıııı öneriler sunmak üzere yapılmıştır.

\section{KAVRAMSAL ÇERÇEVE}

\section{El Sanatları ve Turizm İlişkisi}

En kısa tanımıyla kültür; bir topluluğun geçmişten günümüze kadar biriktirdiği değerler bütünüdür (Sarıkaya Hünerel ve Er 2012: 180). Kültür, toplumların tarihi, yaşam şekilleri ve inançlarına dair bilgileri içinde barındırır. Yöre kültürüne ait ögeleri görebileceğimiz en önemli olgu ise el sanatlarıdır. (Sarıkaya Hünerel ve Er, 2012). Kültürün en somut mirası olan el sanatları; kıyafet, mutfak eşyaları, ziynet eşyaları, yöresel çalgılar gibi çok farklı alanlara işlemiş̧tir (Öztürk, 2005; Akın, 2018). Anadolu, binlerce yıl boyunca pek çok farklı medeniyet yaşamış, haliyle pek çok farklı kültür iç içe yaşamaktadır. 1071 yılından sonra Anadolu'ya yerleşmeye başlayan Türkler, hali hazırda zengin bir kültüre sahip iken Anadolu'nun farklı kültürleriyle kendi kültürlerini birleştirip çok daha zengin bir sentez oluşturmuşlardır (Can, 2013; Akın, 2018).

İnsanlar el sanatlarına duygularını, sanat anlayışını, düşüncelerini insanlara aktarmaya çalışmışlardır. El sanatları somut olmayan kültürel miras kapsamınsa değerlendirilmektedir. Somut olmayan kültürel miras, gelenekler, örf ve adetler, yöresel danslar ya da yöreye ait ve yöresel teknikler kullanılarak yapılan sanatsal ürün ve faaliyetler olarak tanımlanabilmektedir (Özbek ve Çevik, 2018; McKercher ve du Cros, 2002). 
II. Dünya Savaşı'nın ardından turizm sektörü önem kazanan bir sektör haline gelmiştir. Turizm sektörü yalnızca gelişmiş ya da gelişmekte olan ülkeler için değil az gelişmiş ülkeler için de büyük gelir kapısı olarak görülmektedir. İnsanlar kendi kültürlerini tanıtma, kültürel faaliyetler sayesinde para kazanma imkânı bulmuştur. 1970'li yılların sonlarına doğru popüler olan ve 80'li yıllarda pek çok insanın turizme katılmasıyla birlikte turizm, ekonomiye de büyük katkılar sağlamaya başlamıştır (Kurgun ve Yamuk, 2013: 27). Alternatif turizmin gelişmesi ve insanların kültür turizmine yönelmesiyle birlikte el sanatları turizm sektöründe önem kazanmaya başlamıştır. El emeği göz nuru ürünlerin turistler tarafından çok ilgi görmesi, el sanatlarının turizm sektöründe önemli bir yere sahip olmasını sağlamıştır (Güdü Demirbulat, Özdemir ve Bozok, 2015: 565).

El sanatları ürünleri hem yörenin kültürünü tanıtması bakımından hem de yöre insanına maddi kazanç sağlaması bakımından turist satışları oldukça önemli olduğunu belirtmek mümkündür. El sanatı ürünlerinin en önemli özellikleri; yöresel özelliklere sahip olması, bir mesajının olması ve özgün olmasıdır. Günümüzde turizmde kullanılmak üzere ticari çıkar doğrultusunda seri üretime geçildiği için bu özelliklerin göz önünde bulundurulmadığını söyleyebiliriz (Özgürce ve Yavuz, 2006: 169).

Kültür, uygarlıkların geçmişten günümüze kadar elde ettikleri somut ya da somut olmayan değerlerin gelecek kuşaklara aktarılması, bu değerlerin korunması ve geliştirilmesi geçmiş ve gelecek nesil arasındaki iletişimi arttırmanın yanı sıra kültürel değerin sürdürülebilirliği açısından da oldukça büyük öneme sahiptir. El sanatları da bu kültürel değerler arasındadır (Çelik ve Toprak 2018: 687). El sanatları bir bölgede yaşayan insanların benzer ihtiyaçları doğrultusunda, bölgede bulunan hammaddelerden yapılan ve yıllar boyunca kendini geliştiren, toplumların duygularını aktaran makineye dayalı bir üretimden çok el emeğinin kullanıldığı kültürel anlama sahip ürünler olarak tanımlanabilir (Sarıkaya Hünerel ve Er, 2012; Kurgun ve Yamuk, 2013). Yukarıda açıklanan bilgiler ışığında el sanatları toplulukların yeme-içme alışkanlıkları, dini ve kültürel yaşamları ve günlük yaşamları hakkında önemli bilgiler barındırmaktadır (Çelik ve Toprak 2018: 687). El sanatları, kişilerin yetenek, bilgi ve becerilerine dayanarak yapılan genellikle hammaddesi doğadan elde edilmiş maddeler kullanılarak el yapımı, bulunduğu toplumun kültürüne dair izler taşıyan ürünlerdir (Okyay, 2008; Güdü Demirbulat vd., 2015). El sanatları ilk üretildiği anlarda dünyadaki hammaddeleri kullanma, hâkim olma duygusu ve ihtiyaç duygusu için üretilmiş olsa da zamanla el sanatlarının sanat için üretilmeye başlamıştır (Çiçekoğlu, 2014; Güdü Demirbulat vd., 2015). Turizm, kültürlerin dünyaya tanıtılmasında önemli rol oynayan bir sektör olarak bilinmektedir. Bir yörenin kültürünü tanıtacak somut öge olan el sanatları da bu yüzden turizmde yöre kültürünün tanitılmasında oldukça büyük öneme sahiptir. Son zamanlarda yalnız el sanatları bile turistik çekicilik unsurları arasında gösterilmektedir. (Güdü Demirbulat vd., 2015: 567).

Gelişen dünya ve teknoloji ile zamanla yok olmaya yüz tutan zanaatkârlar ve el sanatları ürünleri, turizm sektörünün büyümesi ve insanların hediyelik eşya ürünü olarak yöreye has el sanatlarını almak istemesi sebebiyle tekrar canlandığı bilinmektedir. El sanatlarına olan talep artışı yöre insanı için yeni bir istihdam sağlamış, köylerden kentlere olan göçü yavaşlatmış ve yöre halkının yaşam standartlarını yükseltmiştir (Çelik ve Toprak, 2018: 688). Kültür mirası turizmi kapsamında el sanatları önemli bir turistik çekiciliğe sahip olmaya başladığını söylemek mümkündür (Köybaşı, 2006; Çelik ve Toprak, 2018). Turizmde el sanatlarını yeri yöresel hediyelik eşyaları satın alma güdüsüyle yer edinmiştir. El sanatları yalnızca kültür tanıtımı açısından önemli değil, yörenin gelişimine, istihdam sahası sağlaması açısından da oldukça büyük öneme sahiptir (Bayazit vd., 2012; Çelik ve Toprak, 2018). Turizm sektörü sayesinde sürdürülebilirliği devam eden el sanatları kuşaktan kuşağa kültür aktarımı görevini de üstlenmektedir. Bunun yanı sıra turizm sektöründe kültür-sanat ürün pazarlamasında ön 
sıralarda yer alan Türkiye için el sanatları ürünler oldukça büyük önem taşımaktadır. (Öztürk, 2005: Güdü Demirbulat vd., 2015). Turizm sektörü yalnızca turistik gezi faktörünü içinde barındırmaz. Planlama, gezi, ören yerine ziyaret, ikamet edilen yere dönüş ve geziyi hatırlatıcı ögelerden oluşan turizm faaliyetinde, geziyi hatırlatıcı öge olarak el sanatları oldukça büyük öneme sahiptir. Satın alınan el sanatları ürünleri tekrar ziyaret etme niyetini de beraberinde getirme özelliğine sahiptir. (Günal, 2006; Güdü Demirbulat vd., 2015). Turizm, bir ürünün tanıtılmasında oldukça büyük öneme sahip bir endüstridir. El sanatları da turizm aracılı̆̆ ile farklı kültürlerin beğenisine sunulan, turistik çekicilik unsurlarından biri olarak görülmekte ve son yıllarda önemli bir turizm ürünü haline gelmiştir (Bayazit, Ceylan ve Saylan, 2012: 901- 902). El sanatları ürünlerinin turistler tarafından tercih edilmesi için ürünlerin otantik olması ve tarihi ve kültürel bir bütünlük ve özgünlük içinde olması gerekmektedir (Markwick, 2001: 34). Ziyaretçiler içinde tarihi, kültürü ve yörenin otantik havasını yanında taşımak ve seyahati hatırlama güdüsüyle el sanatları ürünlerine ilgi göstermektedir. Eskiden beri var olan bu güdü, kırsal turizm ve kültür turizmi gibi turizm çeşitlerinin çoğalması ile birlikte son zamanlarda zanaatkârlara yeniden ekmek kapısı olmaya başlamıştır. Turizmin çeşitlenmesinin ardından artan turist sayısı ile birlikte el sanatları ürünlerine olan talebin artması sebebiyle el sanatları ve turizm artık ayrılmaz bir ikili olarak görülmeye başlanmıştır ( Bayazit, Ceylan ve Saylan, 2012: 901- 902).

Türkiye, oldukça farklı kültürleri içinde barındıran Anadolu topraklarına sahip olması sebebiyle pek çok farklı somut olmayan kültürel mirasa sahip olduğunu söylemek mümkündür. Özbek ve Çevik'in (2018) yaptığı çalışmada Türkiye'nin 12 milyar dolarlık turizm gelirleri içinde en büyük gelir getiren unsurun el sanatları ürünleri olduğunu belirtmiştir. Bu kapsamda el sanatları ürünleri kültür pazarlaması ve tanitılacak destinasyon hakkında ön bilgi vermek, yalnız değerlerimizi korumak ve sürdürülebilirliğini devam ettirmekle kalmamakta, ekonomik açıdan da ülkeye büyük katkılar sağlamaktadır (Bayazit, Ceylan ve Seylan, 2012; Özbek ve Çevik, 2018).

\section{Sinop İline Ait El Sanatları}

Sinop ili, gösterişli tarihinin de etkisiyle oldukça güzel ve özel el sanatları örneklerine sahiptir. Her yörede kendine has özellikleri ile yer alan çemberler çok eskiden beri dokunan ve başörtüsü olarak kullanılan bir dokuma ürünü olarak Sinop halkı tarafından da kullanılmıştır. Özellikle Boyabat, Durağan ve Saraydüzü ilçelerinde daha sık kullanıldığı bilinmektedir. Günümüzde başörtüsü olarak kullanımının yanı sıra masa, sehpa gibi yüzeylerde örtü olarak ya da gömlek ve elbiselerde de model veya aksesuar olarak da kullanılmaya başlanmıştır. Çember düzen adı verilen dokuma tezgâhlarında, tarak boyuna göre genellikle 50-60 cm eninde ve 100-120 cm boyunda dokunur. Kenarları şerit halinde orta kısmı bütün olarak desenlidir. Çemberin üzerine dokuma yapılırken demir kırat, kibrit kabı, baygın gibi nakışlar atılır (http://www.sinop.gov.tr/). Mahrama adı verilen bir diğer el sanatı havlu ya da bel kuşağı olarak kullanılmak üzere yapılan, ince ve uzun bir şekilde farklı renklerde pamuk ipliği kullanılarak yapılan bir dokuma türüdür. (Sinop Valiliği, 2019). Yörenin diğer sanatlarından peşkir el ve yüz havlusu olarak işlev görmekte, mahramayla benzer fakat daha ince ve uzun teknikte dokunmaktadır (http://www.sinop.gov.tr/).

Günümüzde Sinop'un sembol ürünü haline gelmiş olan gemi ve kotracılık, 1950'li yıllarda Sinop Cezaevi'nde yatmakta olan iki mahkûm tarafından yapılmaya başlanmıştır. Mahkûmların cezaevinden çıktıktan sonra da Sinop'ta kalması ve şehirdekilerin de ilgisiyle şehre hızla yayılmıştır. İlk yıllarda Sinop Limanı'na gelen yolcu vapurlarındaki ziyaretçilere hediyelik eşya olarak sunulan kotralar, yıllar geçerek ününe ün katmış ve Sinop'un simge el sanatı ürünü haline gelmiştir. Günümüzde pek çok şehre hediyelik eşya olarak gönderilen kotralar yerli ve yabancı turistlerin en çok ilgisini çeken ürünler arasında yer almaktadır. Yapımında; ceviz, gürgen, kayın, 
kavak, dişbudak, akçaağaç gibi bölgede oldukça sık bulunan ağaçlar ve misina, naylon ip ve çeşitli kumaşlar kullanılmaktadır (http://www.sinop.gov.tr/). Bir diğer önemli ürünü ise bıçaktır. Sinop' ta Özekeş ve Yılmaz aileleri tarafından başlatılan el yapımı bıçak üretimi günümüzde Özekeş ailesinin dördüncü kuşak ustaları tarafından devam ettirilmektedir. 1890 yılında hobi olarak başlayan bu sanat zamanla ilerlemiş ve el yapımı bıçaklar Sinop'un uluslararası tanıtımına büyük katkı sağlayan el sanatları ürünlerinden biri haline gelmiştir. Bıçakların yapımında yüksek karbonlu İsveç takım çeliği, saplarının yapımında ise manda, geyik boyunuzu, gül ağacı kökü kullanılmaktadır. Korkuluk ve tepe malzemesi kaliteli pirinçten, kınları ise kaliteli sığır derisinden yapılmaktadır (http://www.sinop.gov.tr/). Keten dokuma sanatı ise yapımı hayli uzun süren ve emek isteyen el sanatlarından biridir. Temmuz ayında ekimi yapılan ketenler, daha sonra çeşitli işlemlerden geçerek ip şeklini almaktadır. Yörede "düzen" adı verilen dokuma tezgâhlarında 30, 40 ya da $50 \mathrm{~cm}$ eninde dokunur. Sinop ili Ayancık ilçesinde oldukça önemli bir yere sahiptir (http://www.sinop.gov.tr/).

\section{Sinop İline Ait El Sanatları Örnekleri}

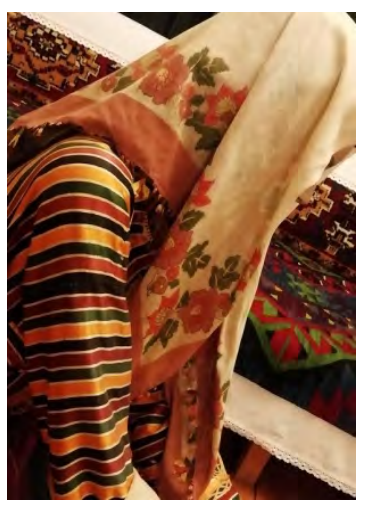

Şekil 1. Çember Örneği

Kaynak:Yazar tarafından çekilmiştir.

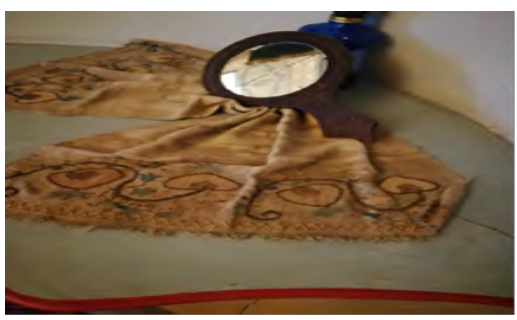

Şekil 3: Peşkir Örneği

Kaynak: Yazar tarafından çekilmiştir.

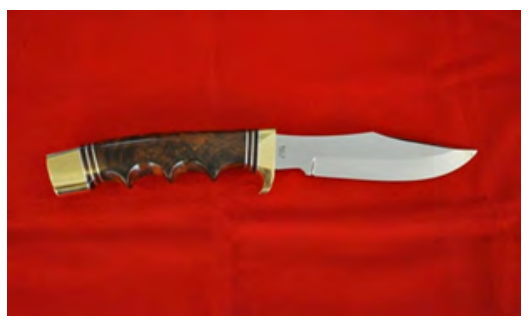

Şekil 7. Bıçak Örneği

Kaynak:www.kulturportali.gov.tr

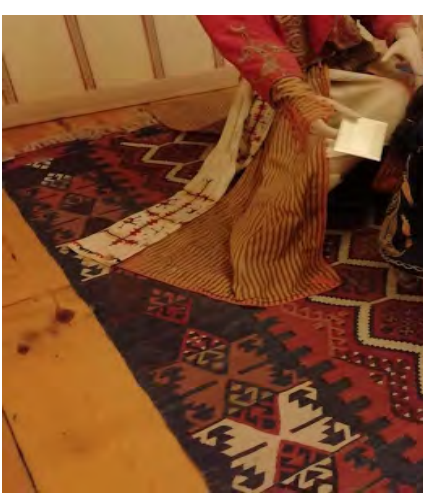

Şekil 2. Mahrama Örneği

Kaynak: Yazar tarafından çekilmiştir.

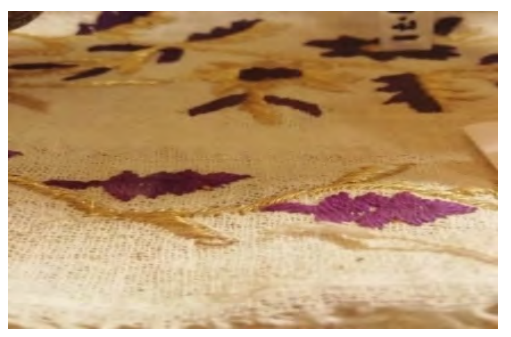

Şekil 4: Keten Dokuma Örneği

Kaynak: Yazar tarafından çekilmiştir.

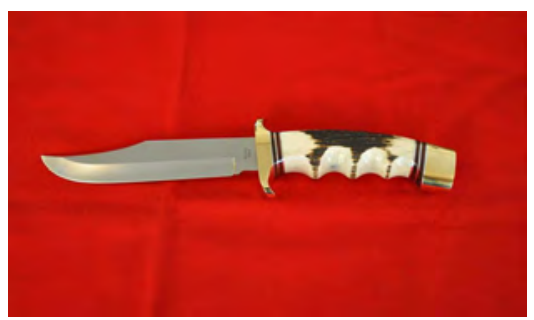

Şekil 8. Bıçak Örneği

Kaynak: www.kulturportali.gov.tr 


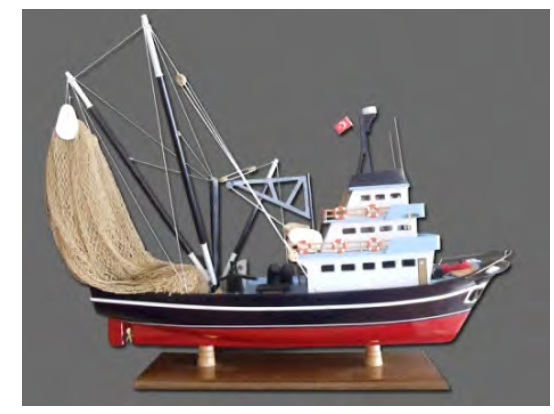

Şekil 8. Gemi Kotra Örneği

Kaynak: www.ulgentekne.com.tr

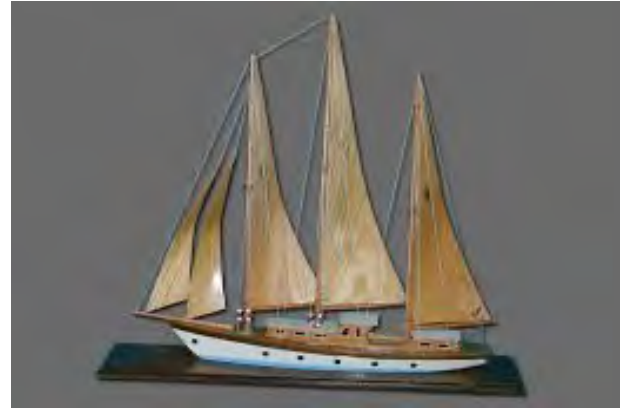

Şekil 8. Gemi Kotra Örneği

Kaynak: www.ulgentekne.com.tr

\section{YÖNTEM}

Araştırmanın amac1; Sinop ilinin geleneksel el sanatlarının turizme katkısının saptanması, Sinop ili el sanatlarının mevcut durumunun değerlendirilmesi, Sinop ilinde yaşayan el sanatlarıyla uğraşan zanaatkârların ve Sinop ili el sanatlarının karşılaştığı sorunların belirlenmesi ve bu sorunlara çözüm önerileri getirilmesidir. Sinop ilinin el sanatlarını yerel ve uluslararası tanınırlı̆̆a ulaşmasını sağlamak ve el sanatlarının sürdürülebilirliğini korumak da çalışmanın amaçlarından biridir. Çalışma, zanaatkârlara sunacağı ek gelir yolu ve kültürün korunması açısından oldukça büyük bir öneme sahiptir. El sanatlarının unutulan veya unutulmaya yüz tutmuş eserler arasından kurtarılması, tekrar hayata ve ticarete kazandırılması açısından da büyük öneme sahiptir. Araştırmada araştırmacılar tarafından sıklıkla kullanılan nitel araştırma tekniği kullanılmış; araştırmanın amaç ve önemine uygun olması açısından mülakat tekniği tercih edilmiştir. Çalışmada amaçlı örnekleme yöntemlerinden tipik durum örnekleme yöntemi kullanılmıştır. Mülakatta kullanılan sorular; Kurgun ve Yamuk (2013) ve Erkol Bayram'ın (2018) çalışmalarından yararlanılarak oluşturulmuştur. Araştırma Covid-19 pandemisinin ilk çıktı̆̆ı, seyahat ve sokağa çıkma yasaklarının olduğu dönemde yapıldığı için görüşmelerde 5 zanaatkâr ile çevrimiçi görüşme gerçekleştirilmiştir. Değerlendirmeye uygun olmayan görüşme bulunmamaktadır. Verilen yanıtlar olduğu gibi aktarılmıştır. Araştırmada nitel yöntemin tercih edilmesinin başlıca sebebi; herhangi birinin verilen sorulara olan cevaplarını bulmak yerine zanaatkârlık mesleğini profesyonel anlamda gerçekleştiren kişilerin sorunlarını, fikirlerini ve pazarın durumunu anlamaktır (Erkol Bayram, 2019; Türnüklü, 2000). Katılımcıların verdiği yanıtlar kayıt cihazı ya da not alma yöntemi ile kayıt altına alınmıştır ( Erkol Bayram, 2019; Yıldırım ve Şimşek, 2008). Veriler 2019 yılına aittir. Çalışmanın Sinop ilini kapsaması, ulusal ve uluslararası literatürde konu ile benzer çalışmaların kısıtlı sayıda olması çalışmanın sınırlılıkları arasında yer almaktadır. Araştırmanın Covid-19 pandemisinin yükseldiği, seyahat ve sokağa çıkma yasağının uygulandığı dönemde yapılmış olması örneklemde yeterli sayıya ulaşılamaması çalışmanın bir diğer sınırlılığı arasında yer almaktadır.

\section{BULGULAR}

Araştırmanın bu kısmında; 5 katılımcı ile gerçekleştirdiğimiz mülakat sonuçlarına yer verilmiştir. Yarı yapılandırılmış mülakat formu ile gerçekleştirilen görüşmeler nitel araştırma yöntemine uygun analiz edilmiştir. Görüşme yapılan katılımcılara ilişkin demografik veriler, açık uçlu sorulara verilen cevaplar içerik analizine tabi tutularak değerlendirilmiştir 


\section{Demografik Özelliklere İlişkin Bulgular}

Katılımcılara ilk olarak demografik sorulara yöneltilmiştir. Katılımcılar genellikle orta yaşlıdır. Katılımcıların yaş aralığı 35-65 yaştır. Beş katılımcının ikisi kadın, üçü erkektir. Kadın katılımcıların eğitim seviyesi, erkek katılımcıların eğitim seviyesinden daha yüksektir. Kadın katılımcıların eğitim seviyesi ön lisans ve yüksek lisans iken erkek katılımcıların eğitim seviyesi ortaokul ve lise seviyesindedir. Katılımcılar genellikle deneyimli kişilerdir deneyim süreler 5-50 yıl arasında değişiklik göstermektedir. Katılımcıların kazançları aya, mevsime, gelen turist sayısına göre değişim göstermektedir.

\section{Araştırma Problemlerine İlişkin Bulgular}

\section{El Sanatlarının Üretim Aşamasına Yönelik Bulgular}

Örnek soru yorumlama; Katılımcılara el sanatlarının üretim aşamasına ilişkin çeşitli sorular yöneltilmiştir. İlk olarak, katılımcılara uygulanan eğitimlerle ilgili "Zanaatkârlar üretime başlamadan önce herhangi bir eğitim sürecine tabii tutuluyor mu sorusu?" yöneltilmiştir. Araştırmaya katılan Zanaatkârların büyük bir kısmı alanla ilgili bir yükseköğretim kurumundan mezun olmadıklarını, mesleki anlamda ve bireysel çabaları ile kendilerini yetiştirdiklerini ifade etmişlerdir. Ayrıca zanaatkârlar usta çırak ilişkisine dayalı bir eğitime tabi olduklarını dile getirmişlerdir. Bu konuya ilişkin örnek katılımcı görüşleri aşağıdaki gibidir;

"Çırak olarak yetiştim ben. Benden öncekiler de benim oğlum da bu meslek ile ilgili çırak eğitimi alıyor tabii." (Katılimcı 1)

"Tabii. Öncelikler mobilya atölye marangozluk işinden anlaması lazım." (Katılımcı 2)

"Tabii ki. Şöyle söyleyeyim; bu işi yapmak isteyen kadınlara ben önderlik yapıyorum, kimin eli neye yatkınsa o konuda onu yönlendiriyorum. Biz genellikle Sinop'a özgü eski danteller, dokumalar, sandiktan çıkma gibi ürünleri restore edip, aslına özgü yeniden üretiyoruz. Bazılarını kıyafetlerde de kullanıyoruz. Dikiş, kesim, oyası hakkında eğitim veriyorum." (Katılımcı 5)

Katılımcılara yöneltilen bir diğer soru ise; “Üretim aşamasında ürünün boyu, ağırlı̆̆ı, rengi gibi kararlarn kim veriyor?" şeklindedir. Genellikle üretim aşamasında bulunan kişilerin ürün ile ilgili kararları verdiği gözlemlemiştir. Bu konuya ilişkin örnek katılımcı görüşleri aşağıdaki gibidir;

"Kendimiz karar veriyoruz." (Katılımeı 3)

"Üretim aşamasında çalışanlar karar veriyorlar." (Katılımoı 4)

"Kim tasarladıysa ona bırakıyorum." (Katılımcı 5)

Katılımcılara ürünlerin orijinalliği ve markalaşma süreci hakkında “Ürünlerinizi marka olarak nitelendirebilir misiniz? Ürünü benzerlerinden ayıran nedir?" sorusu yöneltilmiştir. Katılımcılar, ürünlerinin şekil model ve işçilik açısından farklı olduğunu belirtmiş ve her bir katılımcı ürünlerinin marka niteliğine sahip olduğunu ifade etmiştir. Bu konuya ilişkin örnek katılımcı görüşleri aşağıdaki gibidir;

"Marka tescilimiz var zaten Türkiye ve dünyada tanınıyoruz. Ürünümüzü diğer bıçaklardan ayıran özellikler ise meslek sırrı." (Katılımcı 1)

"Evet kesinlikle. Sinop'un el sanatlarının en eşsiz desenleri bizde bulunmaktadır."(Katılımcı 5) 
Ürünün niteliğine dayalı olarak katılımcılara yöneltilen son soru "Fiyat belirlenirken hangi hususlar göz önünde bulunduruluyor?" şeklinde olmuştur. Katılımcıların her birinin verdiği cevap birbiri ile benzerlik göstermektedir. Katılımcılar emeğe, kullanılan malzemeye ve ürünün boyutuna göre fiyatlandırma işlemini yaptıklarını belirtmiştir. Bu konuya ilişkin örnek katılımcı görüşleri aşağıdaki gibidir;

"İlk önce eme ği, boyutuna göre fiyat belirliyoruz." (Katılımcı 2)

"Yaptığımız işe göre, işçiliğe göre değişir bizde fiyat. Bazı ürünlerden 10 tane çıkar bazılarından 100 tane. İkisi elbet bir değil." (Katılımeı 3)

\section{El Sanatlarının Satış Durumuna İlişkin Bulgular}

$\mathrm{Bu}$ bölümde katılımcılara ürünlerini pazarlama şekilleri ve satışların günümüzdeki ve gelecekteki beklenen durumları hakkında birtakım sorular yöneltilmiştir. Satışlar hakkında yöneltilen ilk soru "Yaptı̆̆ınız el sanatlarını başka şehirlere de pazarlıyor musunuz? Sorunuzun cevabı evet ise hangi şehirler?" şeklinde olmuştur. Katılımcılar genel olarak ulusal pazarda yer bulduklarını özellikle büyük şehirlere ürünlerini gönderdiklerini belirtmişlerdir. Bu konuya ilişkin örnek katılımcı görüşleri aşağıdaki gibidir;

"Türkiye'de tanınıoruz bu yüzden Türkiye geneline pazarlıyoruz. İstanbul, Ankara, İzmir gibi büyük şehirlere pazarliyoruz." (Katılımoı 1)

“Evet, tüm Türkiye. İsteyen olursa yurtdışına da pazarlıyoruz."(Katılımcı 2)

"Tabii gönderiyoruz, anlaşmalı yerler var. İstanbul, Ege tarafi; Bodrum, İzmir bu yerlere gönderiyoruz." (Katılimcı 3)

Katılımcılara el sanatları ürünlerinin tercihi konusunda iletilen soru "El sanatları ürünlerinin satışları hakkında neler söyleyebilirsiniz?" şeklindedir. Verilen cevaplara göre; kazançlarını günlük satışlara göre belirleyen zanaatkârların Covid-19 sürecinden olumsuz etkilendiği görülmektedir. Seyahat kısıtlamasının olduğu zamanda yapılan çalışma, zanaatkarlar gelen ziyaretçileri azalmasıyla hedef kitleye ulaşmakta zorlanmakta olduğunu belirtmektedir. Bu konuya ilişkin örnek katılımcı görüşleri aşağıdaki gibidir;

"Satışlar şu ara koronadan dolayı durgun." (Katılımoı 1)

“Sezonluk yükseliyordu satışlarımız."(Katılımcı 4)

Katılımcılara yöneltilen "Satışlardan gelecekteki beklentileriniz nelerdir?" sorusuna katılımcıların verdiği cevaplar Covid-19 sürecinin son bulması ve satışların yükselmesini umut ettikleri yönündedir. Bu konuya ilişkin örnek katılımcı görüşleri aşağıdaki gibidir;

"Yükselmesini umut ediyoruz."(Katılımol 2)

"Koronanın bitip satışların eski düzenine gelmesi şu anlık en büyük beklentim aslında."(Katılımcı 4)

Katılımcılara satışlar hakkında yöneltilen son soru ise "Satış için farklı bir iletişim aracı kullanıyor musunuz? "dur. Gelişen dünyaya uyum sağlamaya başlayan zanaatkarlar da satış için sosyal medya araçlarından faydalandıklarını belirtmişlerdir. Bu konuya ilişkin örnek katılımcı görüşleri aşağıdaki gibidir;

"Telefon, mail, sosyal medya" (Katılımo 1).

"Telefonla arayabiliyorlar ya da internetten bize ulaşabiliyorlar" (Katılımoı 4).

"Sosyal medya adreslerimizden de satıyoruz" (Katılımo 5). 


\section{El Sanatları ve Turizm İlişkisine İlişkin Bulgular}

El sanatları ve turizm ilişkisine ilişkin ifadelerin yer aldığı bu bölümün ilk sorusu " $E l$ sanatlarının turistik çekiciliğinin olduğunu düşünüyor musunuz?" şeklindedir. Katılımcıların turizm ve el sanatlarının arasında olumlu bir ilişki olduğu konusunda fikir birliği içinde olduğu gözlemlenmiştir. Katılımcılar el sanatları ürünlerinin satış artışı yaşadığı dönemlerin turizm açısından yoğunlaşan yaz dönemi olduğunu belirtmiştir.

"Tabi düşünüyorum, Yaz sezonu veya fuar döneminde, başka şehirlerde açllan şehir tanıtım stantlarında da Sinop'un el sanatları ürünleri oldukça dikkat çekmekte. Yaz döneminde en çok gelir getiren kaynaklarından biri de el sanatları olduğu da büyük bir gerçektir"(Katılımcı 4).

"Tabii mutlaka. Bir yere gittiğiniz zaman o yörenin el sanatlarına bakarsınız. Buraya gelenlerin de çoğu el sanatlarına çok ilgi gösteriyor" (Katılımcı 5).

Katılımclara yöneltilen "Turistlerin Sinop'un yöresel el sanatları hakkında bilgi sahibi olduğunu düşünüyor musunuz?" sorusunun ardından katılımcıların büyük bir çoğunluğu gelen ziyaretçilerin Sinop'un el sanatları hakkında bilgi sahibi olduğu yönünde olmuştur. Katılımcılar Sinop'un el sanatları ürünlerinin ulusal ve uluslararası ölçüde tanındığını belirtmektedir.

"Tabii. Seneler evvel bir Amerikalıya bir bıçak satmışsam tanıdıkları da mutlaka bıçak almaya gelir. Turistler bizi çok iyi tanır" (Katılımoı 1).

"Genelde bilgi sahibi" (Katılımoı 3).

"Genelde kulaktan dolma bilgi sahibi olarak gelseler de bazı turistler tabii daha önceden araştırıp gelen turistler de var" (Katıllimel 4).

Katılımcılara satışların gelen ziyaretçilerle doğru bir orantısı olup olmadığını belirlemek için “Gelen turist sayısına göre satışlarınızın arttığını söylemek mümkün müdür?" sorusu yöneltilmiştir. Katılımcıların bu konuda da fikir birliği içinde olduğu gözlemlenmiştir. Katılımclar satışların gelen turist sayısı ile arttığını, Covid-19 sebebi ile getirilen seyahat kısıtlaması sonucu satışların epey düştügünü belirtmiştir.

"Evet, Kurvaziyer teknesi bekliyorduk gelemedi, haliyle satılar düştü" (Katılımcı 1).

"Bunu net bir şekilde söyleyebiliriz. Bu yıl turist gelmediği için satışlar da düşük. Gelen turist sayısının artı̆̆ı dönemlerde satışlarımızda gözde görülür bir fark oluyor"(Katılımcı 4).

Turistler tarafından en çok tercih edilen ve Sinop'un en fazla üne sahip olan el sanatı hakkında “Sinop'ta turistlerin en çok aldıkları el sanatı ürünü sizce hangisidir?" sorusu sorulmuş ve tüm zanaatkârlar kotra cevabını vermişlerdir. Bu cevaplardan kotra sanatının Sinop'un simge el sanatı ürünü olduğu ve ziyaretçilerin ortak beğenisini alan yegâne el sanatı ürünü olduğu sonucuna ulaşmak mümkündür.

“Bence kotradır"(Katılımc1 2).

“Gemi maketi alırlar. Zaten başka yerde bulunmuyor" (Katılımcı 3).

“Kotradır diye düşünüyorum" (Katılımcı 4).

\section{El Sanatlarının Karşılaştığı Sorunlar ve Çözüm Önerilerine İlișkin Bulgular}

Katılımclara el sanatlarının karşılaştığı sorunlar ve çözüm önerilerine ilişkin "El sanatlarının günümüzde karşılaştı̆̆ı problemler nelerdir?" sorusu yöneltilmiştir. Her bir katılımcının birbirinden farklı yanıtlar verdiği gözlemlenmiştir. Genel olarak el sanatlarının en çok karşılaştığ 1 
sorunlar arasında ekonomik sorunlar, vasiflı eleman, hammadde ve Covid-19 sebebiyle turist sayısında yaşanan düşüş olarak söylemek mümkündür. Konuya ilişkin bazı yanıtlar;

"Ekonomik durum ve doların yüksek olması satışlarımızı etkiliyor" (Katılımoı 1).

"Ekonomi, çırak yetiştirme, vasıflı eleman bulup geleceğe yönelik el sanatımızın devam etmesi zorlaşıyor" (Katılımol 2).

"Hammadde bulma sorunu çok büyük bir de bu yıl için konuşacak olursak turizmin düşüklüğ̈̈ nedeniyle satışlar da düşǚ"(Katılımcı 4).

Katılımcılara sektörde karşılaştıkları sorunlara ilişkin bir çözüm önerisi getirmeleri için " $B u$ sorunlara çözüm önerileriniz nelerdir?" sorusu yöneltilmiştir. Katılımcılar çırak yetiştirmenin kolaylaşması, yerli ürünlerin kalitesinin artırılarak daha ucuza mal edilmesi, tanıtım ve bilgilendirme faaliyetlerine ağırlık verilmesi gerektiği görüşündedir. Hammadde üretiminin artması, dolara bağlı olarak yabancı hammaddeye olan bağımlılı̆ııın azalması gerekliliğine değinilmiştir. Konuya ilişkin örnek cevaplar;

"Ne olabilir? Ortaokul ikinci sınıftan sonra çıraklık okulu açılabilir. İkinci sorun için de boya vernik gibi ürünlerin yerli üretim ürünlerinin daha kaliteli olmasını bu sayede bizlerin de dolar bazında artış gösteren ürünlere ihtiyaç duymayacak seviyeye gelmek önemli" (Katılımoı 2).

"Bunlar devlet ve belediyenin iş birliği içinde çözülecek şeyler. Ekonomiye belediye bir şey yapamaz, biz bir şey yapamayız ama yerli hammaddenin kaliteli yapılması için, ucuz, yerli ve kaliteli ürüne ulaşmak için çaba sarf edebiliriz. Belediyenin yapacağı iyi bir Sinop reklamı bize daha çok turist kazandıracaktır" (Katılımol 4).

"El sanatları daha çok yaygınlaşmalı. Sinop keten dokumasıyla ünlü ama artık Sinop keten üretmiyor. Sinop'un keten dokumasının bitmemesi için keten üretimini bu şehre getirmek lazım. Hammaddelere daha ucuz bir şekilde ulaşmak lazım. Alternatif seçeneği yok bunun. Üretmek lazım"(Katılımcı 5).

Kurgun ve Yumuk (2013) yaptığı çalışmasında hammadde sorunu, fiyatların el emeğinden dolayı yüksek olması sebebi ile satışlarda azalma ve tanıtım yetersizliğine değinilmiştir. Bu araştırmada da elde edilen sonuçlar benzerlik göstermektedir.

Sarıkaya Hünerel ve Er (2012) çalışmasında el sanatlarının unutulmaması gerektiğini, tanıtım ve teşvik faaliyetlerinin artması sonuçlarına ulaşmıştır. Çalışmada da benzer sorunların varlığı tespit edilmiştir. Tanıtım faaliyetlerinin artması ve el sanatı üretimine gençlerin teşvik edilmesi gerektiği tespit edilmiştir.

Bayazit ve arkadaşlarının (2012) yaptığı çalışmada zanaatkarların yerine geçecek, el sanatının devamını sağlayacak eleman bulmada zorluk yaşandığı ve tanıtım yetersizliğinden kaynaklanan satış azlığı sonuçlarına ulaşmıştır. Yapılan araştırma sonucu çalışma da benzer sonuçlara ulaşılmıştır.

\section{TARTIŞMA, SONUÇ ve ÖNERİLER}

El sanatları, kültürün korunması ve sürdürülebilirliği açısından büyük önem arz etmektedir. El sanatları, bir toplumu tanıtabilmenin en somut halidir. El sanatı ürünleri el yapımı olduğu müddetçe bu özelliklerini korumaktadır. Kültürün sürdürülebilirliğini sağlamanın yollarından biri de; turizmde kullanmak ve gelecek nesillere geçmiş kültürü miras bırakmaktır. Kültür yalnızca gelecek nesillere aktarıldığı sürece var olabilir. Bir toplumun kültürü toplumun karakteristik özellikleri hakkında bilgi vermektedir. Bizler ve yeni nesillerin yapması gereken kültürel miraslarımıza sahip çıkmak, onları korumak ve tanıtmaktır. Bu çalışma Sinop şehrinin 
el sanatlarını koruma, turistik ürün olarak kullanma ve gelecek nesillere aktarma açısından büyük önem arz etmektedir.

El sanatları yalnızca turizm için değil yerel halk için de büyük öneme sahip olan kültürel bir değerdir. Kültürel değerleri korumak her bireyin vazifesidir. El sanatları gibi ender ve günlük kullanıma fayda sağlayacak ürünlerin korunması, fabrikasyondan uzak, anıldığı gibi 'el' sanatı olarak icra edilmesi gerekmektedir. Zanaatkârlar el sanatlarının sürdürülebilirliğinde en büyük role sahip kişilerdir. Sürdürülebilirliğin devamı için zanaatkârlar teşvik edilmeli ve desteklenmelidir. Usta-çırak eğitiminin sona ermesinden sonra kalifiye eleman bulmakta zorlanan el sanatları için eleman yetiştirecek okul açılmalıdır. El sanatları ortaya çıktığı yöreyi temsil eder. Daha önce orada bulunan hammaddelerin artık tarımının yapılmaması hammadde sorununa, dolayısıyla fiyat artışına sebep olmaktadır. Hammaddelerin yerli olması hem yöredeki çiftçiliğin gelişimine, hem zanaatkârların ucuz fiyatla kaliteli ürüne ulaşımının kolaylaşmasına hem de fiyatların düşmesine yardımcı olacaktır. Bu sayede Sinop ticaretinin yeniden canlanacağı düşünülmektedir.

Literatür incelendiğinde yaklaşık 10 yıl önceki sorunların günümüzde de devam ettiğini söylemek mümkündür. Çalışmada elde edilen sonuçlar literatürdeki sonuçlarla benzerlik göstermektedir. Önceki çalışmalarda elde edilen sonuçlar hammadde yetersizliği, eleman bulmada yaşanılan zorluk, pahalı olması sebebiyle turistlerin satın almak istememesi ve tanıtım faaliyetlerine ağırlık verilmesi gerektiği belirtilmiştir. Araştırma sonucu benzer sonuçlar elde edilmiştir.

Araştırma kapsamında elde edilen sonuçlar; el sanatı eğitiminin küçük yaşta verilmesi, yerli hammadde üretimi, daha ucuza kaliteli hammaddeye ulaşılabilme, el sanatı ürünleri fiyatları konusunda halkı bilgilendirme, üretilen ürünleri ihraç etmek isteyen zanaatkâra imkân sağlanma ve Sinop şehri için reklam ve tanıtım faaliyetlerine ağırlık verilmesi şeklindedir.

Bu kapsamda, halkı bilgilendirmek için okullarda ya da şehir meydanlarında el sanatları hakkında bilgilendirici etkinlikler düzenlenmeli, meslek edindirme kursları ya da meslek liselerinde el sanatları ile ilgili çalışmalara ağırlık verilmesi çalışmanın önerileri arasında yer almaktadır. İstanbul (İSMEK), Ankara (BELMEK), İzmir (İZMEB), Konya (KOMEK) ve Sakarya (SAMEK) gibi meslek edindirme kurslarının Sinop ilinde de faaliyete girmesi çalışan yetiştirme açısından büyük kolaylık sağlayacaktır. El sanatları çalışmalarına ağırlık verilmesi, farklı bölgelerin el sanatı ürünlerinin yaşadığı sorunlar ve çözüm önerilerine dair ya da el sanatlarının gelişimine katkı sağlayacak farklı çalışmalar yapılması çalışmanın önerileri arasında yer almaktadir.

Gelişen ve değişen dünyada yeni turizm eğilimine bakıldığında, kültürlerini olduğu gibi koruyan, sakin, şehir stresinden uzak kırsal kentler göze çarpmaktadır. Kırsal kentlerin en büyük pazarlama araçlarından biri ise el sanatlarıdır. El sanatlarının sürdürülebilirliği belediyeler, zanaatkârlar ve halkın işbirliği ile sağlanmalı ve bir sonraki nesle aktarılmalıdır.

\section{KAYNAKÇA}

Akın, A. (2018), El Sanatlarının Turizme Etkisi: Gaziantep Örneği, AïBÜ Sosyal Bilimler Enstitüsü Dergisi, 18(3): 241-263.

Altıntaş, K. M. (2016). Kaybolmaya Yüz Tutmuş Geleneksel Türk El Sanatkârlarının Karşı Karşıya Bulunduğu Ticari Sorunların Analizi, Bilig 77: 157-182. 
Aydın, E. ve Selvi, M.S. (2012). Kırsal Turizm Tanıtımında Yerel Paydaşların Rolü: Arhavi Örneği, Uluslararası Sosyal ve Ekonomik Bilimler Dergisi, 2 (2): 133-144.

Bayazit, M., Ceylan, U. ve Saylan, U. (2012) Geleneksel El Sanatlarının Bölge Turizmine Etkisi: Güneydoğu Anadolu Bölgesi, Batman Üniversitesi Yaşam Bilimleri Dergisi, 1 (1): 899-908.

Can, M. (2013). Geleneksel Türk El Sanatlarının Turizme ve Ekonomiye Katkısı, Sosyal ve Beşeri Bilimler Dergisi 5 (2): 259-266.

Çelik, S. ve Toprak, L. S. (2018), Şırnak Geleneksel El Sanatlarının Turistik Ürün Olarak Değerlendirilmesi, Anemon Muş Alparslan Üniversitesi Sosyal Bilimler Dergisi, 6(5): 687-692.

Çiçekoğlu, N. (2014). Somut Olmayan Kültürel Miras Taşıyıcıları: Rize El Sanatı Ustaları Üzerine Bir İnceleme, Yayınlanmamış Yüksek Lisans Tezi, Gazi Üniversitesi, Ankara.

Erkol Bayram, G. (2018), Kadın Girişimciler ve Turizm: Mevcut Durum ve Sorunlar Üzerine Sinop İlinde Bir Araştırma, İşletme Araştırmaları Dergisi, 10(2): 56-88.

Erkol Bayram, G. (2019), Sinop İlinin Turizm Odaklı Gelişimine Dair Turist Rehberlerinin Rolleri ve Görüşleri, Turist Rehberliği Dergisi, 2(2): 57-71.

Etikan, S. ve Çukur, T. (2011). Kırsal Turizm Faaliyetlerinin Çomakdağ-Kızılağaç Köyü El Sanatları Üzerine Etkisi Süleyman Demirel Üniversitesi Güzel Sanatlar Fakültesi Hakemli Dergisi, 08: $1-15$.

Güdü, Demirbulat, Ö., Özdemir, S. S. ve Bozok, D. (2015), El Sanatları ve Turizm İlişkisi Çerçevesinde Türk Halı Dokumacılığının UNESCO Somut Olmayan Kültürel Miras Listesinde Yer Alan Örnekler Doğrultusunda Değerlendirilmesi, 14. Geleneksel Turizm Paneli Bildiriler Kitabı, Ahmet Faik Abasıyanık Kültür Merkezi, Sakarya. ss: 64-579.

Günal, V. (2006). Mardin İlinde Kültürel Çekicilikler ve Turizm Amaçl Kullanım Olanakları, Yayınlanmamış Doktora Tezi, Ankara Üniversitesi, Ankara.

http://www.sinop.gov.tr/el-sanatlari [Erişim Tarihi: 02.03.2020]

http://www.ulgentekne.com.tr/ulgentekne.php [Erişim Tarihi: 17.09.2020]

http://www.ulgentekne.com.tr/urunler.php?urun=36 [Erişim Tarihi: 17.09.2020]

https://www.kulturportali.gov.tr/turkiye/sinop/nealinir/bicak [Erişim Tarihi: 17.09.2020]

Kesici, M. (2012). Kırsal Turizme Olan Talepte Yöresel Yiyecek ve İçecek Kültürünün Rolü KMÜ Sosyal ve Ekonomik Araştırmalar Dergisi, 14 (23): 33-37.

Köybaşı, N. (2006). Boş Zaman Sosyolojisi ve Boş Zamanları Değerlendirme Aracı Olarak Dinlence Turizmi ve Kültür Turizmine Katılan Yerli Turistlerin Karşılaştırmalı Sosyolojik Analizi, Yayınlanmamış Yüksek Lisans Tezi, Anadolu Üniversitesi, Eskişehir.

Kurgun, H. ve Yumuk, Y. (2013). Yöresel El Sanatlarının Kültürel Turizmin Gelişimindeki Rolü: Görece (Boncukköy) ve Nazarköy Örnekleri, Uluslararası Sosyal ve Ekonomik Bilimler Dergisi, 3(1): 27-32.

Markwick, M. C. (2001). Tourism and The Development of Handicraft Production in The Maltese Islands. Tourism Geographies, 3(1), 29-51.

McKercher, B. and du Cros, H. (2002), Cultural Tourism: The Partnership Between Tourism and Cultural Heritage Management, Binghamton: Haworth Press.

Okyay, G. (2008). Trabzon Yöresi Geleneksel El Sanatlarından Hasır Örgüsü ve Kazazlı̆̆ın Araştırılması ve Öğretim Programı Önerisi, Yayınlanmamış Yüksek Lisans Tezi, Gazi Üniversitesi, Ankara. 
Özbek, Ö. ve Çevik, S. (2018), Somut Olmayan Kültürel Mirasın Taşıyıcısı Olarak Geleneksel El Sanatları: Gönen İlçesinin Yaşayan Mirası, Journal of Tourism and Gastronomy Studies, 6 (4): 588603.

Özgürce, G. ve Yavuz, C. (2006). El Sanatları Ürünlerinin Bulunduğu Yöreye Sosyo Ekonomik Etkileri ve Katkıları (Ordu İli Örneği), Uluslararası Katılımlı Sanat Ekonomisi Sempozyumu,1-2 Aralık. Çanakkale. ss: 167-183.

Öztürk, İ. (2005). Türk El Sanatlarının Günümüzdeki Durumu (Tarihçe, Sorunlar, Öneriler). Atatürk Üniversitesi Güzel Sanatlar Fakültesi Dergisi, 7: 67-75.

Sarıkaya Hünerel, Z. ve Er, B. (2012). Halk Kültürünün Tanıtılmasında El Sanatlarının Yeri Veri Önemi, Batman Üniversitesi Yaşam Bilimleri Dergisi, 1 (1): 179-190.

Torun, E. (2013). Kırsal Turizmin Bölge İnsanına Katkıları, KMÜ Sosyal ve Ekonomik Araştırmalar Dergisi, 15 (24): 31-37.

Türnüklü, A. (2000). Eğitim Bilim Araştırmalarında Etkin Olarak Kullanılabilecek Nitel Bir Araştırma Tekniği: Görüşme, Kuram ve Uygulamada Eğitim Yönetimi, 6 (24), 543- 559.

Yıldırım, A. ve Şimşek, H. (2005). Sosyal Bilimlerde Nitel Araştırma Yöntemleri, Ankara: Seçkin Yayınları 